\title{
Calcium- and mucin-binding proteins of staphylococci
}

\author{
Virginia L. Thomas, ${ }^{*}$ Barbara A. Sanford and Mary A. Ramsay \\ Department of Microbiology, The University of Texas Health Science Center at San Antonio, \\ San Antonio, Texas 78284-7758, USA
}

(Received 29 June 1992; revised 19 October 1992; accepted 28 October 1992)

\begin{abstract}
The association of staphylococci with the mucus gel that overlays the mucosa of the respiratory tract may lead to clearance of cocci or, in certain conditions such as cystic fibrosis (CF), to colonization. In the present study, a quantitative radioassay was used to study the effect of $\mathrm{Ca}^{2+}$, which is elevated in $\mathrm{CF}$ sputa, on the adhesion of ${ }^{3} \mathrm{H}$ labelled Staphylococcus aureus to submaxillary gland mucin immobilized in MaxiSorp 96-well, break-apart modules. $\mathrm{Ca}^{2+}$ significantly enhanced the adhesion of $S$. aureus (five strains) and Staphylococcus epidermidis (four strains). The reaction was specific because adhesion was not enhanced in the presence of $\mathrm{Mg}^{2+}, \mathrm{Ca}^{2+}+$ EGTA (a $\mathrm{Ca}^{2+}$ chelator) or protamine and was not attributable to hydrophobicity of the test strains. Staphylococcal adhesion was significantly $(P \leqslant 0.005)$ blocked in the presence of highly sialated and sulphated reagents, which suggests that $\mathrm{Ca}^{2+}$ binds to the sialic acid and sulphate residues of immobilized mucin. The $\mathrm{Ca}^{2+}$-binding sites on the surface of $S$. aureus were trypsin-sensitive; in addition, ${ }^{125} I$-labelled solubilized $S$. aureus surface proteins reacted with immobilized mucin in a direct binding assay, and the reaction was significantly enhanced by $\mathrm{Ca}^{2+}$. Autoradiography demonstrated that ${ }^{45} \mathrm{Ca}$ bound directly to two polypeptides $\left(M_{\mathrm{r}} 170000\right.$ and 150000$)$ of solubilized staphylococcal surface proteins separated by SDS-PAGE, and that ${ }^{125}$ I-labelled mucin bound directly to three staphylococcal polypeptides $\left(M_{\mathrm{r}} 40000,35000\right.$, and 29000). These results suggest that $S$. aureus adhesion to mucin is mediated by at least two mechanisms: via $\mathrm{Ca}^{2+}$-binding surface proteins in the presence of $\mathrm{Ca}^{2+}$ and via mucin-binding surface proteins unrelated to $\mathrm{Ca}^{2+}$.
\end{abstract}

\section{Introduction}

It is well known that Staphylococcus aureus is an initial and chronic colonizer of the mucus gel present in the airways of patients with cystic fibrosis (CF) (Burns \& May, 1968; Goerging et al., 1990; Marks, 1990). Bauernfeind et al. (1987) reported a longitudinal study of sputa from 102 patients with CF in which the incidence of $S$. aureus and $S$. epidermidis was approximately $36 \%$. Kilbourn (1978) hypothesized that the increased concentration of $\mathrm{Ca}^{2+}$ which is present in sputa of $\mathrm{CF}$ patients makes the sputum susceptible to colonization by $S$. aureus. Subsequent in vivo studies have shown that $S$. aureus, $S$. epidermidis and $S$. saprophyticus have the capacity to associate with the mucus gel coating the upper respiratory tract of ferrets, and in vitro these staphylococci bind specifically to immobilized purified mucin in a quantitative solid-phase radioassay (Sanford et al., 1989). Growth conditions of the staphylococci

*Author for correspondence. Tel. (210) 5673914 ; fax (210) 567 6612 .

Abbreviation: $\mathrm{CF}$, cystic fibrosis. affected their capacity to bind to mucin in vitro; growth in the presence of insoluble complexes of calcium magnesium phosphate significantly enhanced adhesion to mucin. The present study examines the role of calcium in the adhesion of staphylococci to immobilized mucin by use of a modification of the original radioassay and also partially characterizes the staphylococcal adhesins and mucin receptors.

\section{Methods}

Media and reagents. The following media and chemical reagents were used: M199, a chemically defined medium modified with Earle's salts and containing L-glutamine, $\mathrm{pH} 7 \cdot 2$ (Grand Island Biological Co.); Hanks' balanced salt solution (HBSS; Gibco); phosphate-buffered saline, pH 7.2 (PBS); FTA haemagglutination buffer (BBL); Tween 20 (Fisher Scientific Co.); heparin (from bovine lung, 1000 USP units $\mathrm{ml}^{-1}$; Organon Inc.); recombinant lysostaphin (Applied Microbiology); $\left[\right.$ methyl $\left.-{ }^{3} \mathrm{H}\right]$ thymidine (specific activity $15 \mathrm{Ci} \mathrm{mmol}^{-1}, \quad 555 \mathrm{GBq}$ $\mathrm{mmol}^{-1}$; ICN); ${ }^{125} \mathrm{I}$ (specific activity $17.0 \mathrm{mCi}$ per $\mu \mathrm{g}$ iodine; Amersham); sodium phosphate (dibasic heptahydrate; Aldrich); sodium iodide (Aldrich); Bio-Rad protein assay (Bio-Rad); ${ }^{45} \mathrm{Ca}$ (calcium chloride in water; specific activity $17.96 \mathrm{mCi} \mathrm{mg}^{-1}, 665 \mathrm{MBq}$ $\mathrm{mg}^{-1}$; Du Pont); Liquiscint scintillation cocktail (National Diagnostics); phenylmethylsulphonyl fluoride (PMSF; United States Biochemical); Rainbow protein molecular mass markers [myosin (200 kDa), phosphorylase $b(97 \cdot 4 \mathrm{kDa})$, bovine serum albumin $(69 \mathrm{kDa})$, 
ovalbumin $(46 \mathrm{kDa})$, carbonic anhydrase $(30 \mathrm{kDa})$, trypsin inhibitor $(21.5 \mathrm{kDa})$, and lysozyme $(14.3 \mathrm{kDa})$; Amersham]. The remaining reagents were purchased from Sigma: purified mucin type 1-S (from bovine submaxillary glands), which is qualitatively similar in chemical composition to human respiratory mucin (Nisizawa \& Pigman, 1959) and asialomucin; fetuin (from foetal calf serum) and asialofetuin (type I); glycophorin A (from human blood) and asialoglycophorin A; acid hydrolysate of casein (amicase, from bovine milk); $\mathrm{CaCl}_{2} ; \mathrm{MgCl}_{2}$; assay kits for colorimetric determination of the concentrations of calcium and of magnesium, which were used according to the manufacturer's instructions; EGTA; trypsin type 1; sodium metaperiodate; dextran sulphate $\left(M_{\mathrm{r}} 500000\right)$; de- $N$-sulphated heparin (from porcine mucosal heparin); troponin (from bovine muscle); sodium dodecyl sulphate (SDS); glycerol; $\beta$-mercaptoethanol; bromophenol blue; gelatin; Nonidet P-40; and, Coomassie Brilliant BlueR250.

Bacteria. Five strains of $S$. aureus were used: strain $\mathrm{Ci}-1$, which was isolated from the lung of a patient who died from post-influenzal staphylococcal pneumonia (Sanford et al., 1986); strains CF837 and CF845, which were both isolated from the sputa of two patients with $\mathrm{CF}$ and were obtained from John R.W. Govan, University of Edinburgh, UK; prototype strain 8325-4 and its protein-A-deficient isogenic mutant, DU5723 (Patel et al., 1987), kindly supplied by T. J. Foster, University of Dublin, Ireland. In addition, four strains of $S$. epidermidis were used: the slime-producing strain RP62A (ATCC 35984) and its non-slime-producing mutant strain RP62NA (Schadow et al., 1988) both supplied by G. B. Pier, Channing Laboratory, Boston, MA, USA; and CONS 61w and CONS 52, which were clinical isolates obtained from infected premature neonates in Medical Center Hospital, San Antonio, Tx, USA. Bacteria were labelled by inoculation of each $50 \mathrm{ml}$ volume of $\mathrm{M} 199$ with $1-2 \times 10^{8}$ c.f.u. of staphylococci in a tissue culture flask $\left(150 \mathrm{~cm}^{2}\right.$; Corning) and in the presence of $10 \mu \mathrm{Ci}$ of $\left[\right.$ methyl $\left.{ }^{-3} \mathrm{H}\right]$ thymidine per $\mathrm{ml}$ of medium. Bacteria were incubated in stationary culture at $37^{\circ} \mathrm{C}$ for $18 \mathrm{~h}$, harvested by centrifugation at $8000 \times \mathrm{g}$ for $30 \mathrm{~min}$ at $5{ }^{\circ} \mathrm{C}$, suspended in HBSS, and stored at $-70^{\circ} \mathrm{C}$. Several aliquots were repeatedly washed with sterile deionized $\mathrm{H}_{2} \mathrm{O}$ and freeze-dried for determination of dry weight. C.f.u. were determined by the standard agar overlay procedure.

In vitro radioassay. ${ }^{3} \mathrm{H}$-labelled staphylococci were assayed for the capacity to bind to immobilized mucin by a modification of an earlier procedure (Sanford et al., 1989). Mucin $(100 \mu \mathrm{l} ; 250 \mu \mathrm{g}$ dry wt), diluted in $0.1 \mathrm{M}$-carbonate buffer, $\mathrm{pH} 9.6$, was added to individual wells in MaxiSorp 96-well, break-apart modules (Nunc) and incubated at $37^{\circ} \mathrm{C}$ for $18 \mathrm{~h}$. Modules were stored at $4{ }^{\circ} \mathrm{C}$ until needed. Before a test run, each well of immobilized mucin was treated with $200 \mu$ l blocking buffer $\left(0.5 \%\right.$ casein $/ 0.05 \%$ Tween 20 in PBS) for $60 \mathrm{~min}$ at $37^{\circ} \mathrm{C}$ and then drained. This step blocked sites not sensitized with mucin. In addition, control wells which did not contain immobilized mucin were treated with blocking buffer. The test bacteria were thawed, washed three times in PBS, and suspended in PBS to a concentration of approximately $60 \mu \mathrm{g}$ dry wt for $S$. aureus $\left(\sim 2 \times 10^{8}\right.$ c.f.u. $)$ and approximately $150 \mu \mathrm{g}$ dry wt for $S$. epidermidis $\left(\sim 4.6 \times 10^{8}\right.$ c.f.u. $)$ per $50 \mu \mathrm{l}$ volume. Labelled staphylococci $(50 \mu \mathrm{l})$ were added to each well and incubated at $37^{\circ} \mathrm{C}$ for $60 \mathrm{~min}$. Unbound bacteria were removed by aspiration and the wells were gently washed with PBS until all unbound staphylococci had been removed as determined by examination with an inverted microscope. Wells were drained, and each well was submerged in $7 \mathrm{ml}$ scintillation cocktail. Radioactivity was determined in a liquid scintillation spectrometer (Tracor Analytic model 6895; Tracor Instruments). D.p.m. were corrected for background and for quenching by use of external standards and were converted to ng staphylococci, as previously described (Sanford \& Ramsay, 1987). Control values were subtracted from test values and results expressed as mean corrected ng bound to immobilized mucin. All assays were done at least in triplicate.
Hydrophobicity. The surface hydrophobicity of $S$. aureus test strains, grown in M199 as described above, was measured by the procedure of Rosenberg et al. (1980). Hydrophobicity is expressed as percentage adsorption to hexadecane.

Pretreatment of staphylococci. ${ }^{3} \mathrm{H}$-labelled staphylococci were rinsed in PBS and suspended at a concentration of $500 \mu \mathrm{g}$ (dry wt) of staphylococci $\mathrm{ml}^{-1}$ in PBS (pH 6.1) only, or in PBS that contained trypsin type 1, sodium metaperiodate or PMSF. Bacterial suspensions were incubated at $37^{\circ} \mathrm{C}$ for $90 \mathrm{~min}$; bacteria suspended in the periodate solution were incubated in the dark. Pretreated bacteria were washed in PBS and used in the in vitro radioassay.

Preparation of surface-labelled proteins of $S$. aureus. Surface proteins of staphylococci were labelled as follows. A fresh culture of $S$. aureus (200-300 mg wet wt), grown in M199 as described, was suspended in $0.5 \mathrm{ml} 50 \mathrm{mM}-\mathrm{Na}_{2} \mathrm{HPO}_{4}$ buffer, $\mathrm{pH} \mathrm{7.4}$, and transferred to a vial that contained five activated Iodo-beads (Pierce) and $1 \mathrm{mCi}$ of ${ }^{125} \mathrm{I}$. Beads were activated according to the manufacturer's instructions. The vial was placed in ice and gently agitated for $15 \mathrm{~min}$. The reaction was terminated by separation of the bacterial suspension from the activated Iodo-beads. Labelled bacteria were washed repeatedly in buffer containing $1 \mathrm{mg}$ of $\mathrm{NaI} \mathrm{ml} \mathrm{m}^{-1}$ with a final wash in $10 \mathrm{mM}-\mathrm{Tris} / \mathrm{HCl}$, $15 \mathrm{~mm}-\mathrm{NaCl}, \mathrm{pH} 7 \cdot 4$. Bacteria were pelleted by centrifugation, suspended in $5 \mathrm{ml} 25 \%(\mathrm{w} / \mathrm{v})$ sucrose in PBS containing $200 \mu \mathrm{g}$ lysostaphin $\mathrm{ml}^{-1}$, and incubated at $37^{\circ} \mathrm{C}$ for $30 \mathrm{~min}$ with agitation. The suspension was centrifuged $\left(10000 \mathrm{~g}\right.$ for $30 \mathrm{~min}$ at $\left.5{ }^{\circ} \mathrm{C}\right)$, and the supernatant fluid, which contained solubilized surface-labelled proteins, was filtered $(0.45 \mu \mathrm{m})$, heated at $60^{\circ} \mathrm{C}$ for $30 \mathrm{~min}$, and dialyzed (dialysis membrane tubing, $3500 M_{\mathrm{r}}$ cutoff, Spectrum Medical Industries) in repeated changes of deionized $\mathrm{H}_{2} \mathrm{O}$ at $4{ }^{\circ} \mathrm{C}$. A colorimetric assay, utilizing Coomassie Brilliant Blue G-250, was used to determine total protein concentrations according to the instructions of the manufacturer (Bio-Rad). Surface-labelled proteins were tested for direct binding to immobilized mucin in the radioassay.

Separation of surface proteins. The surface proteins of $S$. aureus, grown in M199, were solubilized by treatment with lysostaphin, dialysed, and total protein was determined. Specimens were freezedried and stored at $-20^{\circ} \mathrm{C}$ until needed. The solubilized surface proteins were dissolved in buffer [0.0625 $\mathrm{M}$-Tris $\mathrm{HCl}(\mathrm{pH} \mathrm{6.8)}, 2 \%$ $(\mathrm{w} / \mathrm{v})$ SDS, $10 \%(\mathrm{v} / \mathrm{v})$ glycerol, $5 \%(\mathrm{w} / \mathrm{v}) \quad \beta$-mercaptoethanol, $0.02 \%$ bromophenol blue] without heating, and subjected to electrophoresis $(120 \mathrm{~V}$ constant current) on a $5 \%(\mathrm{w} / \mathrm{v})$ stacking and $10 \%$ $(w / v)$ resolving SDS-polyacrylamide electrophoresis gel according to the method of Laemmli (1970). Separated polypeptides were electroeluted out of the gel on to untreated nitrocellulose paper (NCP) by electrophoresis at a constant current of $20 \mathrm{~mA}$ for $24 \mathrm{~h}$ in buffer $(14 \%$ (w/v) glycine, $0.3 \%$ Tris, $20 \%(\mathrm{v} / \mathrm{v})$ methanol). NCP strips were used in direct binding assays with ${ }^{45} \mathrm{Ca}$ and ${ }^{125} \mathrm{I}$-labelled mucin. Duplicate gels were stained for proteins using the Bio-Rad silver stain according to manufacturer's instructions (Bio-Rad) and counterstained with Coomassie blue as described by Dzandu et al. (1984).

Direct binding of calcium to staphylococcal surface proteins. NCP strips that contained separated polypeptides of $S$. aureus solubilized surface proteins were assayed for $\mathrm{Ca}^{2+}$ binding activity by the method of Maruyama et al. (1984). Troponin, a protein that contains a $\mathrm{Ca}^{2+}$ binding subunit, was included as a positive control. Briefly, the strips were soaked in buffer $\left(60 \mathrm{~mm}-\mathrm{KCl}, 5 \mathrm{mM}-\mathrm{MgCl}_{2}, 10 \mathrm{~mm}\right.$-imidazole$\mathrm{HCl}, \mathrm{pH} \mathrm{6.8)}$, incubated in buffer that contained $1 \mathrm{mCi}^{45} \mathrm{Ca}$ for each $100 \mathrm{ml}$ for $18 \mathrm{~h}$ at $25^{\circ} \mathrm{C}$, rinsed with $50 \%(\mathrm{v} / \mathrm{v})$ ethanol for $5 \mathrm{~min}$, dried in air, and exposed to Cronex video imaging film ( $\mathrm{Du}$ Pont) with a Quanta-III CK intensifying screen (Du Pont) at $-70^{\circ} \mathrm{C}$.

Direct binding of mucin to staphylococcal surface proteins. Forty milligrams of mucin were labelled with ${ }^{125} \mathrm{I}$ by the chloramine $\mathrm{T}$ method of Daugharty et al. (1972). Labelled mucin was dialysed against 
repeated changes of PBS to remove unbound label and stored at $4{ }^{\circ} \mathrm{C}$ [specific activity 143 c.p.m. $(\mu \mathrm{g} \text { mucin })^{-1}$ ]. The NCP strips were placed in buffer [ $50 \mathrm{~mm}-\mathrm{Tris} / \mathrm{HCl}(\mathrm{pH} 7.5), 0.15 \mathrm{M}-\mathrm{NaCl}, 0.25 \%$ gelatin, $0.15 \%$ sodium azide, and $0.1 \%$ Nonidet P-40] that contained $5 \%$ $(\mathrm{w} / \mathrm{v})$ bovine serum albumin (BSA) for $1 \mathrm{~h}$, and then rinsed four times with buffer that did not contain BSA. Strips were soaked for $1 \mathrm{~h}$ in multiple changes of buffer ( $60 \mathrm{~mm}-\mathrm{KCl}, 5 \mathrm{~mm}-\mathrm{MgCl}_{2}, 10 \mathrm{~mm}$-imidazole/ $\mathrm{HCl}$, pH 6.8), overlaid with this same buffer that contained ${ }^{125} \mathrm{I}$ labelled mucin (total activity $2.86 \times 10^{6}$ c.p.m.), and allowed to incubate for $18 \mathrm{~h}$ at $25^{\circ} \mathrm{C}$ with gentle agitation. Strips were washed four times in $50 \%$ ethanol, allowed to set in $50 \%$ ethanol for $5 \mathrm{~min}$ with agitation, air-dried, and processed for autoradiography as described above.

Statistical analysis. The arithmetic means, standard deviation and standard error of the means were determined for each set of data. Where appropriate, comparisons were made by a single-factor analysis of variance by the Student unpaired $t$ test (two tailed) using the StatView 512 + computer package (BrainPower, Calabasas, CA, USA).

\section{Results}

Effect of calcium on the adhesion of staphylococci to immobilized mucin.

The adhesion of labelled staphylococci to immobilized mucin in the presence of various concentrations of calcium is shown in Fig. 1. All three test strains of $S$. aureus gave a dose response curve and demonstrated significantly enhanced adhesion in the presence of $\mathrm{Ca}^{2+}$.

\section{Specificity of adhesion}

$\mathrm{Ca}^{2+}$-enhanced adhesion was seen with two additional test strains of $S$. aureus: $8325-4$ and its protein Adeficient mutant DU5723 (Fig. 2). The fact that DU5723 was adhesion-positive indicated that protein $\mathrm{A}$ was not the adhesin that mediated $\mathrm{Ca}^{2+}$-enhanced binding. The

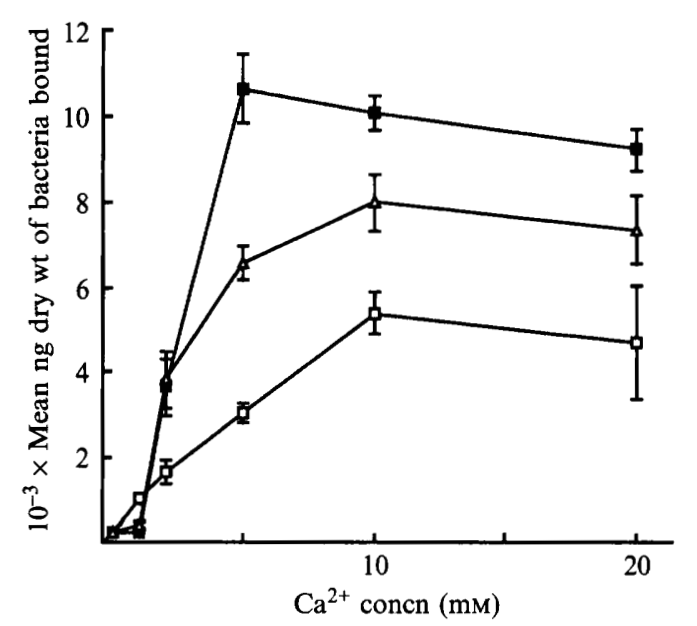

Fig. 1. Mean corrected adhesion of ${ }^{3} \mathrm{H}$-labelled $S$. aureus to immobilized mucin. Concentration of $\mathrm{Ca}^{2+}\left(\mathrm{mM} \mathrm{l}^{-1}\right)$ is indicated per $50 \mu \mathrm{l}$ of bacterial suspension per well. Bars represent standard error of the means of eight samples. Specific activity [d.p.m. ( $\mu \mathrm{g}$ dry wt of staphylococci) ${ }^{-1}$ ] was: $3.1 \times 10^{3}, \mathrm{Ci}-1 ; 4.4 \times 10^{3}, \mathrm{CF} 837$; and $8.5 \times 10^{3}$, CF845. $\square$, Strain Ci-1; $\square$, strain CF837; $\triangle$, strain CF845. four strains of $S$. epidermidis were also adhesion-positive in the presence of $\mathrm{Ca}^{2+}$. The binding interaction was determined to be specific for $\mathrm{Ca}^{2+}$, because enhanced adhesion was blocked in the presence of EGTA, which is a specific $\mathrm{Ca}^{2+}$ chelator, and adhesion was not enhanced in the presence of $\mathrm{Mg}^{2+}$ or in the presence of highly positively charged protamine. In addition, enhanced adhesion could not be explained by non-specific hydrophobic interactions, because the hydrophobicity of test strains was low $(<26 \%)$ as seen in Table 1.

\section{Characterization of mucin receptor(s)}

A series of experiments were done to determine the effect of sulphated and sialated groups on the binding phenomenon. Results in Table 2 show that $\mathrm{Ca}^{2+}$ enhanced adhesion was significantly decreased $(P \leqslant$ 0.005 ) in the presence of all reagents tested. Substitution of immobilized asialomucin for mucin in the assay wells reduced direct adhesion by a mean of $42 \%$, which suggests that sialic acid is a receptor for $\mathrm{Ca}^{2+}$. These results were supported by the data which showed that highly sialiated fetuin and glycophorin blocked adhesion by a mean of approximately $93 \%$. The fact that asialofetuin and asialoglycophorin also significantly decreased adhesion (mean of $59 \%$ ) suggests that components of these glycoproteins other than sialic acid were involved in the blocking phenomenon. The use of heparin and dextran sulphate, which are rich in sulphate groups but do not contain sialic acid groups, significantly blocked adhesion (mean of approx. 65\%); not surprisingly, heparin with the $\mathrm{N}-\mathrm{SO}_{3}$ groups removed also significantly blocked adhesion but to a lesser extent (mean of $43 \%$ ). Thus, it appears that sulphate groups are involved in the $\mathrm{Ca}^{2+}$ cross-linking of staphylococci to mucin.

\section{Characterization of staphylococcal adhesins}

Table 3 summarizes the results obtained when ${ }^{3} \mathrm{H}$ labelled staphylococci were subjected to various reagents and treatments before use in the in vitro radioassay and compared with untreated controls. The adhesion of all three test strains of staphylococci to immobilized mucin was significantly reduced when the bacteria were treated with trypsin, which suggested that a surface protein(s) was involved in the $\mathrm{Ca}^{2+}$-enhanced adhesion interaction. Because PMSF, a protease inhibitor that irreversibly inactivates trypsin and other proteases, was added to bacterial suspensions with trypsin to stop enzyme activity, the staphylococci were also pretreated with PMSF only as a control. Results showed that the $\mathrm{Ca}^{2+}$ mediated adhesion to mucin was further enhanced in the presence of this enzyme inhibitor; the increase was 


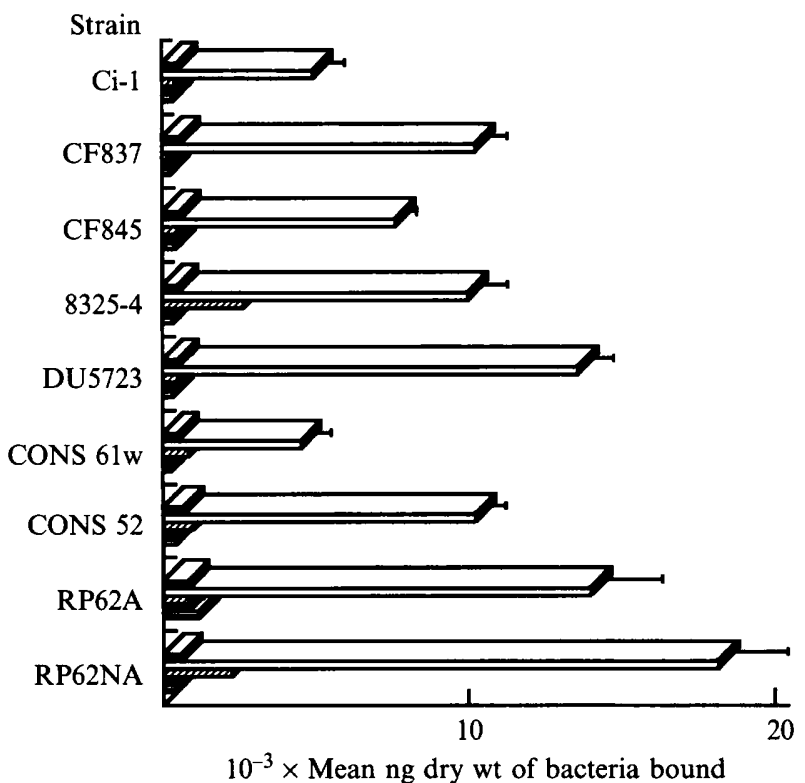

Fig. 2. Mean adhesion of ${ }^{3} \mathrm{H}$-labelled staphylococcal strains to immobilized mucin. To each well was added a $50 \mu$ l of bacteria suspended in PBS diluent only ( $\boldsymbol{E}$ ) or diluent containing one of the following: $\mathrm{Ca}^{2+}\left(10 \mathrm{mM} \mathrm{l}^{-1}\right)(\square), \mathrm{Ca}^{2+}\left(10 \mathrm{~mm} \mathrm{l}^{-1}\right)+\operatorname{EGTA}\left(10 \mathrm{mM} \mathrm{l}^{-1}\right)$ (圆), $\mathrm{Mg}^{2+}\left(10 \mathrm{mM} \mathrm{l}^{-1}\right)$ (圆), or $5 \mu \mathrm{g}$ of protamine (目). Bars represent standard error of the means of three samples. Specific activity [d.p.m. ( $\mu \mathrm{g}$ dry wt of staphylococci) $)^{-1}$ ] was: $6.5 \times 10^{3}, \mathrm{Ci}-1 ; 3.8 \times 10^{3}$, CF837; $4.4 \times 10^{3}$, CF845; $2.2 \times 10^{4}, 8325-4 ; 2.8 \times 10^{4}$, DU5723; $4.5 \times 10^{3}$, CONS $61 \mathrm{w} ; 1.1 \times 10^{4}$, CONS $52 ; 4.5 \times 10^{3}$, RP62A; and $5.9 \times 10^{3}$, RP62NA.

Table 1. Hydrophobicity of the test strains of staphylococci

\begin{tabular}{lc}
\hline \hline Strain & Hydrophobicity (\%)* \\
\hline S. aureus & \\
Ci-1 & 19 \\
CF837 & 15 \\
CF845 & 14 \\
$8325-4$ & 23 \\
DU5723 & 20 \\
S. epidermidis & \\
CONS 61w & 14 \\
CONS 52 & 9 \\
RP62A & 25 \\
RP62NA & 14 \\
\hline
\end{tabular}

* Expressed as percentage adsorption to hexadecane of strains grown in M199 medium.

statistically significant with strain CF845. Carbohydrate surface components did not appear to contribute to the interaction, because periodate treatment of the staphylococci had no significant effect on adhesion.

Results indicated that staphylococcal surface proteins appeared to have a role in $\mathrm{Ca}^{2+}$-enhanced adhesion to mucin. Therefore, ${ }^{125}$ I-labelled surface proteins from strains Ci-1, CF837 and CF845 were tested in a direct
Table 2. Adhesion of S. aureus to immobilized mucin in the presence of sulphate or sialic acid groups

Approximately $458 \mu \mathrm{g}$ (dry wt) of ${ }^{3} \mathrm{H}$-labelled $S$. aureus was suspended in $400 \mu \mathrm{C} \mathrm{Ca}^{2+}\left(10 \mathrm{mM} \mathrm{l}^{-1}\right)$ in PBS alone or PBS containing various concentrations of the test reagents. A $50 \mu \mathrm{l}$ volume of each bacterial suspension was added to each well of immobilized mucin or control well in the radioassay procedure. Corrected mean ng of staphylococci bound \pm SEM was calculated from data from six samples. Data are expressed as the mean percentage of control bound ( \pm SEM) to immobilized mucin, where binding in calcium + PBS alone represented $100 \%$

\begin{tabular}{|c|c|c|c|}
\hline Strain & Test reagent & $\begin{array}{l}\text { Concn } \\
\left(\mathrm{ml}^{-1}\right)\end{array}$ & $\begin{array}{l}\text { Adhesion } \\
\text { (mean \% of } \\
\text { control } \\
\pm \text { SEM) }\end{array}$ \\
\hline $\mathrm{Ci}-1$ & $\begin{array}{l}\text { Fetuin } \\
\text { Asialofetuin } \\
\text { Glycophorin } \\
\text { Asialoglycophorin } \\
\text { Asialomucin* } \\
\text { Dextran sulphate } \\
\text { Heparin } \\
\text { De- } N \text {-sulphated heparin }\end{array}$ & $\begin{array}{l}1.0 \mathrm{mg} \\
1.0 \mathrm{mg} \\
1.0 \mathrm{mg} \\
1.0 \mathrm{mg} \\
\\
0.5 \mathrm{mg} \\
100 \text { USP units } \\
1.0 \mathrm{mg}\end{array}$ & $\begin{array}{r}4 \pm 1 \\
42 \pm 1 \\
12 \pm 3 \\
43 \pm 4 \\
50 \pm 7 \\
39 \pm 2 \\
34 \pm 8 \\
51 \pm 5\end{array}$ \\
\hline CF837 & $\begin{array}{l}\text { Fetuin } \\
\text { Asialofetuin } \\
\text { Glycophorin } \\
\text { Asialoglycophorin } \\
\text { Asialomucin* } \\
\text { Dextran sulphate } \\
\text { Heparin } \\
\text { De- } N \text {-sulphated heparin }\end{array}$ & $\begin{array}{l}1.0 \mathrm{mg} \\
1.0 \mathrm{mg} \\
1.0 \mathrm{mg} \\
1.0 \mathrm{mg} \\
\\
1.0 \mathrm{mg} \\
100 \text { USP units } \\
1.0 \mathrm{mg}\end{array}$ & $\begin{array}{l}4 \pm 1 \\
43 \pm 2 \\
10 \pm 2 \\
46 \pm 7 \\
56 \pm 4 \\
40 \pm 0 \cdot 8 \\
40 \pm 2 \\
60 \pm 4\end{array}$ \\
\hline CF845 & $\begin{array}{l}\text { Fetuin } \\
\text { Asialofetuin } \\
\text { Glycophorin } \\
\text { Asialoglycophorin } \\
\text { Asialomucin* } \\
\text { Dextran sulphate } \\
\text { Heparin } \\
\text { De- } N \text {-sulphated heparin }\end{array}$ & $\begin{array}{l}1.0 \mathrm{mg} \\
1.0 \mathrm{mg} \\
1.0 \mathrm{mg} \\
1.0 \mathrm{mg} \\
\\
0.1 \mathrm{mg} \\
100 \text { USP units } \\
1.0 \mathrm{mg}\end{array}$ & $\begin{array}{l}7 \pm 0 \cdot 9 \\
32 \pm 0 \cdot 8 \\
11 \pm 1 \\
36 \pm 7 \\
68 \pm 4 \\
27 \pm 3 \\
29 \pm 6 \\
60 \pm 3\end{array}$ \\
\hline
\end{tabular}

* In these assays immobilized asialomucin was substituted at the same concentration for the immobilized mucin in the wells.

binding assay in the presence and absence of $\mathrm{Ca}^{2+}$. The results showed that the labelled proteins did bind to immobilized mucin, and that the binding was enhanced in the presence of $\mathrm{Ca}^{2+}$ (Fig. 3); these results seemed to indicate that different proteins mediated the binding to mucin in the presence and absence of $\mathrm{Ca}^{2+}$. Similar results (not shown) were obtained with labelled surface proteins from two other clinical isolates of $S$. aureus, as well as strain 8325-4 and its protein-A-deficient isogenic mutant, DU5723.

Subsequent experiments were done to determine whether the proteins that bound to $\mathrm{Ca}^{2+}$ were, in fact, different from the proteins that bound to mucin. Unlabelled surface proteins of $S$. aureus were solubilized under conditions that prevented lysis of intact cells, separated by SDS-PAGE, blotted on to NCP and reacted with ${ }^{45} \mathrm{Ca}$ and ${ }^{125} \mathrm{I}$-labelled mucin. Results of autoradiography (Fig. 4) demonstrated that ${ }^{45} \mathrm{Ca}$ bound directly to 
Table 3. Adhesion of untreated or pretreated S. aureus to immobilized mucin

\begin{tabular}{ccc}
\hline \hline & & $\begin{array}{c}\text { Adhesion } \\
\text { (mean \% of } \\
\text { control } \pm \text { SEM) }\end{array}$ \\
\hline Pretreatment* & Concn & \\
PMSF & $0.2 \mathrm{mmol} \mathrm{m}^{-1}$ & $150 \pm 14$ \\
Ci-1 & & $132 \pm 15$ \\
CF837 & & $242 \pm 23 \ddagger$ \\
CF845 & $2 \mathrm{mg} \mathrm{ml}^{-1}$ & $18 \pm 7 \ddagger$ \\
Trypsin type I & & $0 \ddagger$ \\
Ci-1 & & $0 \ddagger$ \\
CF837 & & \\
CF845 & $20 \mu \mathrm{g} \mathrm{ml}^{-1}$ & $75 \pm 18$ \\
Trypsin type 1 & & $17 \pm 8 \ddagger$ \\
Ci-1 & & $0 \ddagger$ \\
CF837 & & \\
CF845 & & $130 \pm 36$ \\
Sodium metaperiodate & $10 \mathrm{mmol} \mathrm{ml}^{-1}$ & $66 \pm 16$ \\
Ci-1 & & $119 \pm 6$ \\
CF837 & & \\
CF845 & & \\
\hline \hline
\end{tabular}

* Before use in the radioassay, approximately $500 \mu \mathrm{g}$ (dry wt) ${ }^{3} \mathrm{H}-$ labelled $S$. aureus was suspended in $1 \mathrm{ml}$ PBS (pH 6.1) only or PBS that contained enzyme or enzyme inhibitor (PMSF). Suspensions were incubated at $37^{\circ} \mathrm{C}$ for $1.5 \mathrm{~h}$. Pretreated bacteria were washed with PBS, suspended in PBS that contained $\mathrm{Ca}^{2+}\left(10 \mathrm{mM} \mathrm{l}^{-1}\right)$, and added to wells sensitized with immobilized mucin as described. Corrected mean ng of adherent staphylococci \pm SEM was calculated from data from six samples. Data are expressed as the mean percentage of control bound ( \pm SEM) to immobilized mucin, where adhesion with staphylococci pretreated with PBS only represented $100 \%$.

$\dagger$ PMSF (final concn $0.2 \mathrm{~mm}$ ) was also added at the end of the incubation period to suspensions that contained trypsin, to terminate enzyme activity.

$\ddagger P<0.004$.

two polypeptides with approximate molescular masses of 170 and $150 \mathrm{kDa}$. As expected, ${ }^{45} \mathrm{Ca}$ also bound to troponin (molecular mass $17.5 \mathrm{kDa}$ ). In contrast, ${ }^{125} \mathrm{I}$ labelled mucin bound to three polypeptides with approximate molecular masses of 40,35 , and $29 \mathrm{kDa}$. A stained gel of the solubilized surface proteins separated by electrophoresis (Fig. 4, lane A) showed a minimum of 29 polypeptides, most of which were not reactive with either radiolabelled probe. In addition, when unlabelled $\mathrm{CaCl}_{2}$ $\left(5 \mathrm{~mm}\right.$ and $10 \mathrm{mM}$ ) was used in place of $\mathrm{MgCl}_{2}$ in the diluent for ${ }^{125}$ I-labelled mucin, binding to the three polypeptides was not blocked (data not shown). These data support the conclusion that the surface proteins of $S$. aureus that bind $\mathrm{Ca}^{45}$ are different from the surface proteins that bind mucin in the absence of calcium.

\section{Discussion}

The interaction of bacterial pathogens with mucus gel present on respiratory mucosa may lead to ciliary clearance of bacteria and thereby help keep the lower respiratory tract free of potential pathogens (Florey, 1955; McNabb, 1981). However, the interaction may

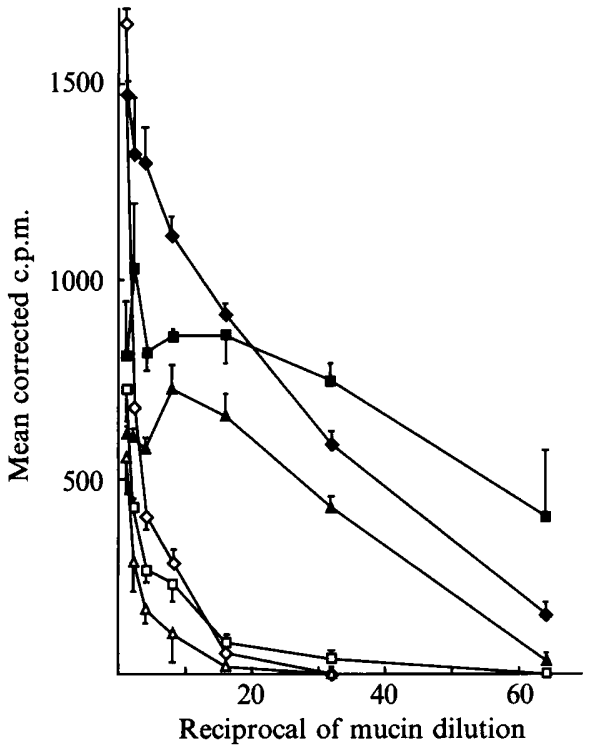

Fig. 3. Binding of $S$. aureus ${ }^{125}$ I-labelled solubilized surface proteins from Ci-1 $(\diamond, \diamond), \operatorname{CF} 837(\triangle, \Delta)$, and CF845 $(\square, \square)$ in PBS only (open symbols) or PBS containing $10 \mathrm{mM} \mathrm{Ca}^{2+} \mathrm{l}^{-1}$ (filled symbols) to twofold serial dilutions of unlabelled mucin (concentration of undiluted mucin, $10 \mathrm{mg} \mathrm{ml}^{-1}$ ) immobilized in wells as described in the text. Results of triplicate determinations are expressed as the corrected mean c.p.m. for bound labelled proteins; bars represent standard error of the means. Specific activity [c.p.m. ( $\mu \mathrm{g}$ of total protein $)^{-1}$ ] was: 1954, $\mathrm{Ci}-1 ; 2338$, CF837; and 2649, CF845).

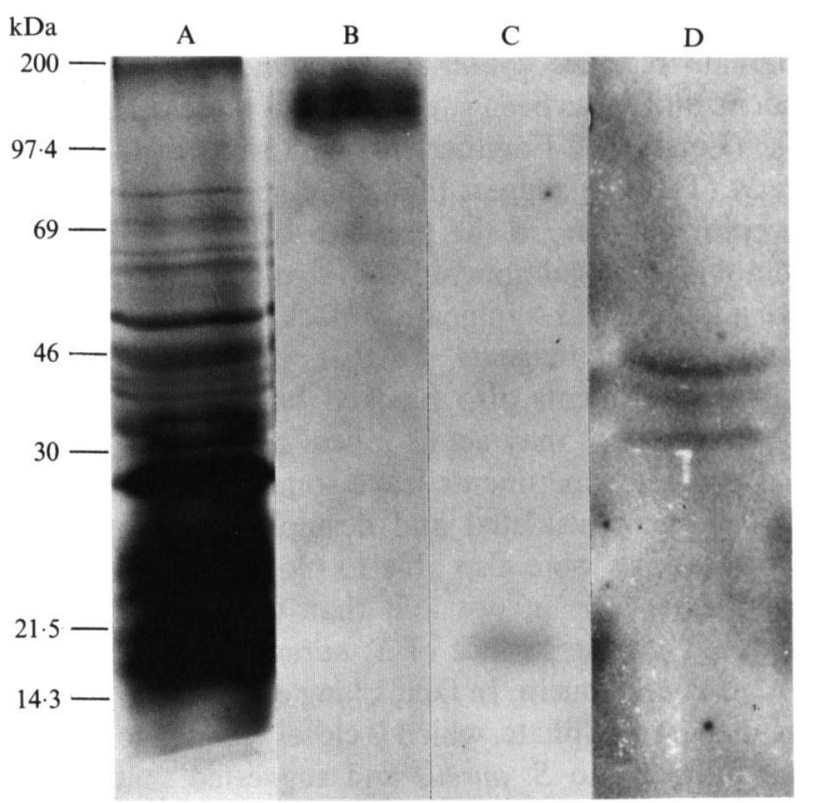

Fig. 4. Solubilized surface proteins (SSP) of $S$. aureus strain DU5723 [180 $\mu \mathrm{g}$ total protein (well A), $360 \mu \mathrm{g}$ total protein (wells B and D)] and $100 \mu \mathrm{g}$ troponin (well C) were subjected to SDS-PAGE. Lane A, polypeptide profile of SSP after staining with silver and Coomassie Brilliant Blue R. Lanes B-D, autoradiographs demonstrating the direct binding of ${ }^{45} \mathrm{Ca}$ to SSP (lane B) and the troponin control (lane $\mathrm{C}$ ), and the direct binding of ${ }^{125} \mathrm{I}$-labelled mucin to SSP (lane D). The positions of molecular mass standards are indicated on the left. Similar results were seen with SSP of strains 8325-4 and CF837 (not shown). 
initiate the infectious process of certain invasive microorganisms if the bacteria have the capacity to attach to and colonize mucus (Freter, 1980), a mechanism that is potentially important in colonization of the respiratory mucosa by staphylococci and Pseudomonas aeruginosa in CF patients (Ramphal, 1990). Kilbourn (1984) reported that the concentration of $\mathrm{Ca}^{2+}$ in sputum specimens from CF patients is high (range of 0.1 to $4.4 \mathrm{~mm} \mathrm{l}^{-1}$ ) and suggested an association between $\mathrm{Ca}^{2+}$ and colonization by staphylococci. Results from the present study show that the presence of $\mathrm{Ca}^{2+}$ actually enhances the adhesion of $S$. aureus, as well as $S$. epidermidis, to mucin (one of the components of sputum) (Figs 1 and 2) and, further, that the enhanced adhesion is specific for $\mathrm{Ca}^{2+}$ (Fig. 2, Table 1). Biesbrock et al. (1991) reported that mucin binding to $S$. aureus in vitro may be dependent on the formation of heterotypic complexing between human salivary low-molecular-mass mucin and secretory $\operatorname{IgA}$; these binding studies were done in the absence of $\mathrm{Ca}^{2+}$ and represent yet another mechanism for the association of staphylococci with mucin.

Results suggest that $\mathrm{Ca}^{2+}$ acts as a bridge to cross-link the surface of the staphylococci to receptors present in immobilized mucin. In the airways, mucin is comprised of sialylated and sulphated glycoproteins which are the major macromolecules of respiratory mucus and comprise a dense number of oligosaccharide units attached to a long polypeptide chain (Roberts, 1978). Sialic acid and sulphate residues confer a strong negative charge on mucin, and it has been suggested that these residues bind $\mathrm{Ca}^{2+}$ (Forstner \& Forstner, 1975). Results of the present study (Table 2) suggest that sialic acid acts as a mucin receptor because, in the presence of $\mathrm{Ca}^{2+}$, adhesion to immobilized asialomucin was significantly decreased, and adhesion was significantly blocked in the presence of highly sialated reagents. Further, the observation that sulphated reagents also blocked binding suggests that sulphate groups may act as mucin receptors. Results of the blocking experiments leave some unanswered questions because asialated and desulphated forms of the same reagents were also able to block binding but to a lesser extent; it is possible that these reagents may interact with the surface of $S$. aureus in the absence of both $\mathrm{Ca}^{2+}$ and mucin. In fact, Liang et al. (1992) reported that heparan sulphate, which is closely related to heparin, binds directly to $S$. aureus and suggested that binding was due to ionic interactions between the cell surface amino groups and the sulphate and carboxyl groups of heparin sulphate.

One other study has demonstrated $\mathrm{Ca}^{2+}$-dependent binding of intact bacterial cells to mucin. Cohen et al. (1985) reported that the adhesion of Escherichia coli F-18 to mouse colonic mucus, immobilized on polystyrene, required $\mathrm{Ca}^{2+}$ but not $\mathrm{Mg}^{2+}$; the role of $\mathrm{Ca}^{2+}$ in this reaction was not defined. In the present study, results suggest that $S$. aureus interacted with mucin by at least two mechanisms: via $\mathrm{Ca}^{2+}$-binding proteins in the presence of $\mathrm{Ca}^{2+}$ and via mucin-binding proteins in the absence of $\mathrm{Ca}^{2+}$. Herrmann et al. (1991) recently described the $\mathrm{Ca}^{2+}$-dependent binding of $S$. aureus to soluble and immobilized thrombospondin. However, the thrombospondin-binding adhesins of $S$. aureus were not sensitive to pretreatment with trypsin, which suggests that these adhesins do not have a protein component and are somehow different from the $\mathrm{Ca}^{2+}$-binding proteins described here. The expression of protein A, a major surface protein of $S$. aureus that binds the Fc part of immunoglobulins (Forsgren \& Sjoquist, 1966), is not required for the $\mathrm{Ca}^{2+}$-dependent or -independent binding to mucin as shown by results obtained with a welldefined protein A-deficient isogenic mutant strain (Fig. 2) and the solubilized surface proteins of this strain (Fig. 4), as well as the results seen with adhesion-positive strains of $S$. epidermidis (Fig. 2) which do not express protein $\mathrm{A}$. Whether the $\mathrm{Ca}^{2+}$-binding or mucin-binding proteins are related to other protein adhesins of $S$. aureus or to any putative adhesins yet to be described for $S$. epidermidis remains to be determined.

In summary, this work represents the first example of specific calcium-binding surface proteins associated with a well-recognized human bacterial pathogen and, furthermore, suggests at least one potential role for these surface proteins, that of the adhesion of $S$. aureus to mucus (mucin). It is important to understand the mechanisms of adhesion of $S$. aureus to mucus and the specific host factors that affect adhesion, particularly in clinical conditions such as $\mathrm{CF}$, in which mucociliary clearance is compromised and the bacteria appear to persist in the respiratory tract by colonization of the mucus.

This work was supported by Cystic Fibrosis Foundation grant G210 (to V.L.T.) and, in part, by Public Health Service grant R01 All7242 (to B.A.S.) from the National Institute of Allergy and Infectious Diseases, National Institutes of Health.

\section{References}

Bauernfeind, A., Bertele, R. M., Harms, K., Horl, G., Jungwirth, R., Petermuller, C., Przyklenk, B. \& Weisslein-Pfister, C. (1987). Qualitative and quantitative microbiological analysis of sputa of 102 patients with cystic fibrosis. Infection 15, 270-277.

Biesbrock, A. R., Reddy, M. S. \& LeVIne, M. J. (1991). Interaction of a salivary mucin-secretory immunoglobulin A complex with mucosal pathogens. Infection and Immunity 10, 3492-3497.

BURNS, M. W. \& MAY, J. R. (1968). Bacterial precipitins in serum of patients with cystic fibrosis. Lancet 1, 270-272.

Cohen, P. S., Arruda, J. C., Williams,T. J. \& Laux, D. C. (1985). Adhesion of a human fecal Escherichia coli strain to mouse colonic mucus. Infection and Immunity 48, 139-145.

Daugharty, D., Warfield, D. T. \& Davis, M. L. (1972). Solid-phase radioimmunoassay of total and influenza-specific immunoglobulin. General Applied Microbiology 23, 360-367. 
Dzandu, J. K., Deh, M. E., Barratt, D. L. \& Wise, G. E. (1984). Detection of erythrocyte membrane proteins, sialoglycoproteins, and lipids in the same polyacrylamide gel using a double-staining technique. Proceedings of the National Acadademy of Sciences of the United States of America 81, 1733-1737.

FLOREY, H. (1955). Mucin and the protection of the body. Proceedings of the Royal Society of London 143, 147-159.

ForsGren, A. \& SJoQuIST, J. (1966). 'Protein A' from S. aureus . I. Pseudo-immune reaction with human $\gamma$-globulin. Journal of Immunology $97,822-827$.

ForstNer, J. F. \& Forstner, G. G. (1975). Calcium binding to intestinal goblet cell mucin. Biochimica et Biophysica Acta 386, 283-292.

FRETER, R. (1980). Prospects for preventing the association of harmful bacteria with host mucosal surfaces. In Bacterial Adherence, pp. 441-458. Edited by E. H. Beachey. London: Chapman \& Hall. Goerging, R. V., Bauernfeind, A., Lenz, W. \& Przyklenk, B. (1990). Staphylococcus aureus in patients with cystic fibrosis: an epidemiological analysis using a combination of traditional and molecular methods. Infection 18, 57-60.

Herrmann, M., Suchard, S. J., Boxer, L. A., Waldvogel, F. A. \& LEW, P. D. (1991). Thrombospondin binds to Staphylococcus aureus and promotes staphylococcal adherence to surfaces. Infection and Immunity 59, 279-288.

KilbouRN, J. P. (1978). Bacterial content and ionic composition of sputum in cystic fibrosis. Lancet i, 334

KILBOURN, J. P. (1984). Composition of sputum from patients with cystic fibrosis. Current Microbiology 11, 19-22.

LAEMmLI, U. K. (1970). Cleavage of structural proteins during the assembly of the head of bacteriophage T4. Nature, London 227, 680-685.

Liang, O. D., Ascencio, F., Fransson, L.-A. \& Wadstrom, T. (1992). Binding of heparan sulphate to Staphylococcus aureus. Infection and Immunity 60, 899-906.

MCNABB, P. C. (1981). Host defense mechanisms at mucosal surfaces. Annual Review of Microbiology 35, 477-496.
MarKs, M. I. (1990). Staphylococcal aspects of cystic fibrosis. Infection 18, 53-56.

Maruyama, K., Mikawa, T. \& Ebashi, S. (1984). Detection of calcium binding proteins by ${ }^{45} \mathrm{Ca}$ autoradiography on nitrocellulose membrane after sodium dodecyl sulphate gel electrophoresis. Journal of Biochemistry 95, 511-519.

Nisizawa, K. \& Pigman, W. (1959). The composition and properties of the mucin clot from cattle submaxillary glands. Archives of Oral Biology 1, 161-170.

Patel, A. H., Nowlan, P., Weavers, E. D. \& Foster, T. (1987). Virulence of protein A-deficient and alpha-toxin-deficient mutants of Staphylococcus aureus isolated by allele replacement. Infection and Immunity 55, 3103-3110.

RAMPHAL, R. (1990). The role of bacterial adhesion in cystic fibrosis including the staphylococcal aspect. Infection 18, 61-64.

ROBERTs, G. P. (1978). Chemical aspects of respiratory mucus. British Medical Bulletin 34, 39-41.

RosenberG, M., GuTNICK, D. \& RosenberG, E. (1980). Adherence of bacteria to hydrocarbons: a simple method for measuring cellsurface hydrophobicity. FEMS Microbiology Letters 9: 29-33.

SANFORD, B. A. \& RAMSAY, M. A. (1987). Bacterial adherence to the upper respiratory tract of ferrets infected with influenza $A$ virus. Proceedings of the Society for Experimental Biology and Medicine 181, 104-111.

Sanford, B. A., Thomas, V. L., Ramsay, M. A. \& Jones, T. O. (1986). Characterization of clinical strains of Staphylococcus aureus associated with pneumonia. Journal of Clinical Microbiology 24, 131-136.

Sanford, B. A., Thomas, V. L. \& Ramsay, M. A. (1989). Binding of Staphylococci to mucus in vivo and in vitro. Infection and Immunity 57, 3735-3742.

Schadow, K. H., Simpson, W. A. \& Christensen, G. D. (1988). Characteristics of adherence to plastic tissue culture plates of coagulase-negative staphylococci exposed to subinhibitory concentrations of antimicrobial agents. Journal of Infectious Diseases 157, 71-77. 